Vesna Lopičić / Biljana Mišić Ilić

JEZIK, KNJIŽEVNOST, KONTEKST

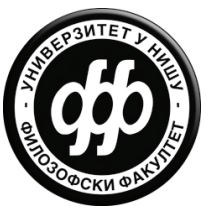




\section{Biblioteka \\ NAUČNI SKUPOVI}

Urednice:

Prof. dr Vesna Lopičić

Prof. dr Biljana Mišić Ilić

Glavni i odgovorni urednik:

Prof. dr Dušan Stamenković

Akademski odbor:

Prof. dr Vesna Lopičić

Prof. dr Biljana Mišić Ilić

Prof. dr Mihailo Antović

Prof. dr Vladimir Ž. Jovanović

Prof. dr Snežana Milosavljević Milić

Prof. dr Dušan Stamenković

Prof. dr Miloš Kovačević

Prof. dr Sofija Miloradović

Prof. dr Željka Babić

Prof. dr Christl Verduyn

Prof. dr Cristóbal Pagán Cánovas

Prof. dr János Kenyeres

Prof. dr Marija Krivokapić

Prof. dr Elżbieta Mańczak-Wohlfeld

Prof. dr Roberta Piazza

Prof. dr Slávka Tomaščíková

Sekretari:

Mladen Popović

Natalija Stevanović

Recenzenti:

Prof. dr Željka Babić

Prof. dr Marija Krivokapić

Prof. dr Jordana Marković 
Univerzitet u Nišu

Filozofski fakultet

\section{JEZIK, KNJIŽEVNOST, KONTEKST \\ LANGUAGE, LITERATURE, CONTEXT}

Tematski zbornik radova

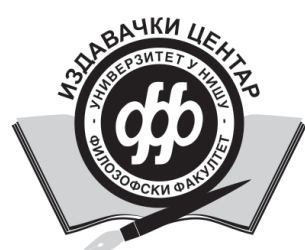

Urednice:

Vesna Lopičić

Biljana Mišić Ilić

Nišs, 2020. 
Recenzenti pojedinačnih radova sa konferencije Jezik, književnost, kontekst:

Mihailo Antović

Vedada Baraković

Zorica Bečanović Nikolić

Savka Blagojević

Nikola Bubanja

Nenad Cekić

Maja Ćuk

Mirjana Daničić

Biljana Dojčinović

Sanja Domazet

Rajna Dragićević

Ana Đorđević

Jasmina Đorđević

Danijela Đorović

Ivana Đuric Paunović

Mina Đurić

Vladimir Figar

Greta Goetz

Milanko Govedarica

Zorica Hadzić

Mirjana Ilić

Ljiljana Janković

Ana Janušević Oliveri

Marina Janjić

Danica Jerotijević Tišma

Aleksandra Jovanović

Ivan Jovanović

Jovana Jovanović

Vladimir Ž. Jovanović

Snežana Kalinić

Aleksandar Kavgić

Jelena Kleut

Miloš Kovačević

Viktorija Krombholc
Maja Kujundžić

Jelena Kusovac

Marija Lojanica

Vesna Lopičić

Goran Maksimović

Maja Marković

Dragana Mašović

Nataša Milivojević

Ana Milojević

Biljana Mišić Ilić

Predrag Mirčetić

Jelena Mitrić

Srđan Orsić

Slobodan Pavlović

Tomislav Pavlović

Vladan Pavlović

Slavko Petaković

Danijela Petković

Aleksandar Petrović

Gordana Pokrajac

Tanja Popović

Tvrtko Prćić

Duško Prelević

Mila Samardžić

Nadežda Silaški

Milica Spremić Končar

Tatjana Trajković

Nataša Tučev

Marta Veličković

Sonja Veselinović

Aleksandra Vukotić

Zorica Vitić

Ana Živković

Dušan Živković 


\title{
Тања Милосављевић
}

Институт за српски језик ${ }^{1}$

Београд

\section{КОНТЕКСТУАЛНЕ МЕТАФОРИЧКЕ РЕАЛИЗАЦИЈЕ ГЛАГОЛА ГОВОРЕЊА У ПРИЗРЕНСКО-ТИМОЧКИМ ГОВОРИМА}

\begin{abstract}
Основне функције говора, физиолошко-акустичка, комуникативна, емотивна и когнитивна, уобличене су у лексичко-семантички систем глагола говорења, који представља доминантну језичку форму свих комуникативних процеса. Модел и садржај комуникације детерминишу семантички потенцијал глаголских лексема, који се актуелизује у конкретној говорној ситуацији. Контекстуално условљене метафоричке значењске реализације глагола говорења откривају многе семантичке димензије општег концепта говор, одражавајући различите аспекте говорног чина, карактеристичне за језичко сазнање дијалекатске језичке личности. Метафорички глаголи имају способност да актуелизују различите аспекте говорне ситуације, ширећи семантички потенцијал дате семантичке класе. Когнитивна вредност метафоричких глаголских реализација повезана је првенствено с њиховом могућношћу да синкретично моделују говорну ситуацију. Метафоричком моделирању подвргнути су различити елементи комуникативног процеса, а анализом је утврђено да су најподложније семантичкој трансформацији спољашње компоненте акта говорења диференциране семама-конкретизаторима: 'интензи-

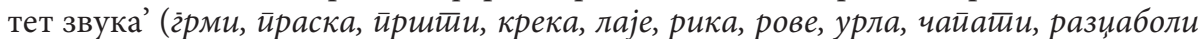
ce, разиаколи се), 'брзина (темпо) говора' (ломоиии, мелье, брбоће), 'нејасност говора' (мумла, мрмға, цамка) и чиниоци интегрисани семантичким знаком 'говори којешта' који реферирају на садржај говора (баје, дрнда, жвака, мелье, итройа,

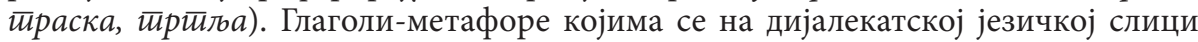
света вербализује концепт говорења поседују велики креативни потенцијал који се актуелизује у говорном чину под утицајем језичког и изванјезичког контекста.
\end{abstract}

Кључне речи: концепт говорења, контекстуална глаголска метафора, призренско-тимочки говори.

Основне функције говора, физиолошко-акустичка, комуникативна, емотивна и когнитивна, уобличене су у лексичко-семантички систем глагола говорења, који представља доминантну језичку форму свих комуникативних процеса. Глаголи говорења непосредно означавају процес говорења у његовим најразличитијим варијацијама.

Овај глаголски микросистем актуелно је поље савремених лингвистичких истраживања због свог комуникативног значаја, квантитативности и употребне вредности. Међутим, у словенској науци још увек није нормиран

\footnotetext{
${ }^{1}$ Овај рад настао је у оквиру пројекта „Дијалектолошка истраживања српског језичког простора” (ЕДБ 178020), који у целости финансира Министарство просвете, науке и технолошког развоја Републике Србије.
} 
класификациони модел глагола говорења, јер ставови лингвиста нису уједначени у погледу лексичко-семантичке и стилско-семантичке организације овог глаголског скупа. У руској науци преовладавају два приступа: с аспекта првог - термин „глаголи говорења” обухвата све глаголе којима је изражен говорни акт, тј. све глаголе који обележавају процес говорења у његовим различитим видовима (И. А. Езолка, М. И Кролль); друго становиште одваја план језика и план говора, разликујући притом појмове „глаголи говорења” и „потенцијални глаголи говорења” (В. П. Бахтина, Р. С. Качинская, према Цыганова 2008). Заступници ове тезе глаголе говорења дефинишу као глаголе који означавају процес говора независно од контекста, док под потенцијалним глаголима говорења или синонимским заменама глагола говорења подразумевају глаголе који у контексту врше функцију глагола говорења. То су полисемични глаголи чије је значење говорења ситуационо условљено и у лексикографским дефиницијама се бележи као секундарно.

Концепт говора на језичкој слици света попуњавају, између осталих, јединице које припадају лексичко-семантичком систему глагола говорења као доминантној језичкој форми изражавања свих комуникативних нијанси. Лексичко-семантичка група глагола говорења базни је репрезент концепта говора и обједињује глаголске лексичке јединице с општом категоријално-лексичком семом 'говор' и класом 'процес', репрезентујући когнитивно моделиране функције и денотативно пространство чина говорења. Овај скуп интегрише све глаголске јединице које садрже семантички примитив 'говорити'. Инваријантна сема денотативног карактера семантички варира у зависности коју димензију говорног акта изражава, најчешће померајући садржај у конотативну сферу, а на том се значењском плану актуелизују емотивно-експресивни елементи стилског и прагматичког типа и функционалностилска компонента. У централној зони концепта ситуиране су семантички и стилски неутралне ознаке којима се денотира процес вербализован доминантом говорийи „служити се говором, саопштавати нешто речима, казивати“. Периферији гравитирају стилски маркиране метафоричке номинације, које категоријални садржај 'говорити' реализују у контексту, ширећи семантички потенцијал дате семантичке класе. ${ }^{2}$

Контексти актуелизују многобројне аспекте општег појма глагола говорења. Метафоричкој модификацији подлежу различити елементи комуникативног процеса, ${ }^{3}$ при чему метафоричке реализације испољавају моделе концептуализације овог когнитивно значајног сегмента објективне стварности за

\footnotetext{
2 „Јединице другостепене номинације (експресиви) преко одређених квазистереотипа носе и чувају информацију о наивној језичкој слици света одређене језичке заједнице, за разлику од јединица првостепене (примарне) номинације које преко одређених стереотипа носе и чувају информацију о концептуалној слици света" (Ристић 2004: 47).

${ }^{3}$ Глаголи говорења су тровалентни, с обзиром на чињеницу да комуникативну ситуацију чине три компоненте: два учесника у комуникацији (говорник и слушалац) и информација коју један актер преноси другоме. Због тога се у контекстима говорна ситуација кристалише управо у аспектима који се реализују у позицијама карактеристичним за глаголе говорења: позиција субјекта (адресанта), позиција објекта (адресата), позиција објекта (садржај исказа).
} 
језичко сазнање и одражавају језичку креативност и лингвокултурне карактеристике носилаца конкретних језика, односно говора.

Когнитивна вредност метафоричких глаголских реализација првенствено је повезана с њиховим потенцијалом да максимално, синкретично моделују говорну ситуацију. Метафоричко моделирање говорне ситуације располаже читавим комплексом језичких средстава, којима се конкретизују димензије комуникативне сфере. Механизмом метафоричке номинације захваћени су следећи аспекти говорне ситуације:

- карактеристике спољне форме говора, његове акустичко-физиолошке особености;

- карактеристике садржаја исказа;

- карактеристике комуникативне стране говора;

- указивање на тип говорне ситуације;

- аспекат намере говорења, подстрекивања конверзације;

- аспекат емоционалног односа говорника према саговорнику и емоционална оцена (Васиьев 1971).

Наведени аспекти нису међусобно потпуно издиференцирани и често се истовремено актуелизују (нпр. упоредо са емоционалним односом и оценом јавља се и компонента која реферира на садржај и тип комуникације; глаголиметафоре који интерпретирају спољашњу страну говора регуларно указују и на емоционално стање говорника, које се конкретизује детаљнијим елементима).

Досадашње анализе глагола говорења у руском језику показују да парадигматски односи унутар групе манифестују законитости неких од аспеката комуникативне ситуације. Најразличитије се метафорички моделује спољна форма речи, израз и комуникативне карактеристике и особености говорног чина. Компаративно истраживање метафоричких номинација говорне активности у руском и енглеском језику (Цыганова 2008) резултира тврдњом да се процес говорења у оба језика означава и метафоричким номинацијама, тј. глаголима са секундарним метафоричким значењем који у датом семантичком пољу реализују номинативну функцију - денотирају процес говорења у контексту комуникативне ситуације. Анализирани глаголи у оба језика показују висок степен сличности у номиновању овог сегмента објективне стварности, што се може објаснити суштинским значајем процеса комуникације као објекта номинације, потребе да се тај процес изрази у јединству свих његових садржајних, формалних, аксиолошких, акустичких, функционалних ознака. У психолошкој перцепцији говора код оба народа примеђује се тенденција тражења паралеле између човековог гласа и других извора звука, јер је и у руском и у енглеском језику семантичка деривација најчешће усмерена на акустичке елементе говорења. Разлике које се испољавају у виду квантитативних и квалификативних неједнакости лексичко-семантичких група и у њиховој унутрашњој организацији детерминисане су етноспецифичним моделима комуникације, као и одсуством деривационе (мотивне) базе у једном језику у односу на други (непостојање глагола чије се основно значење семантички варира). Диференцијација се уочава у искоришћености појединих деривационих база, па је 
тако за енглески језик карактеристичан процес преношења, тј. поимање говора као објекта предаје, преноса, док је за руско језичко сазнање значајан процес употребе објекта, односно говор се схвата као објекат деловања. Ауторка овог компаративног истраживања проналази дистинктивне лингвокултурне црте на основу семантичко-деривационих схема, које манифестују следеће специфичности: већа дистанцираност субјекта од објекта говорења и већа слобода израза присутна је у руској лингвокултури, док је код Енглеза приметан виши степен одговорности за изговорену реч. ${ }^{4}$

Глаголи говорења у савременом српском језику предмет су истраживачке пажње Стане Ристић, која их представља, на примерима облика глагола рећи и

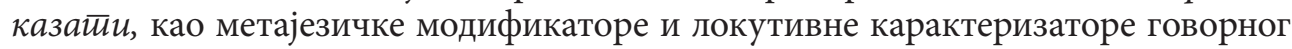
поступка (Ристић 2006, 2007). Испитујући лексичку семантику експресивних глагола, С. Ристић издваја типове глаголских јединица конотативног значења, међу којима 10. парадигми припадају експресиви са семантичким примитивом „рећи / говорити, престати говорити“. Испитивање експресивних глагола и структуре њиховог значења у српском језику (Ристић 2004) показује да експресиви са значењем говорења актуелизују актанте мере, количине, интензитета

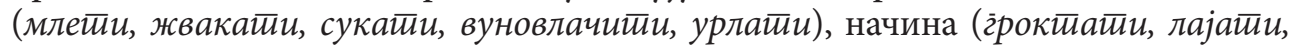

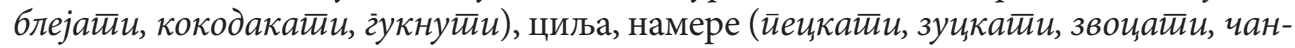

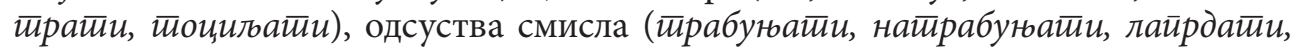

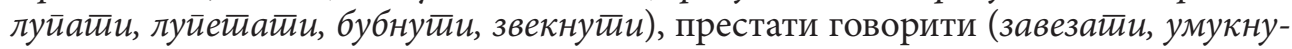
$\bar{u} u)$. У семантици глаголских експресива којима се означава процес говорења реализује се субјективна оцена по параметру пожељности / непожељности, којом се најчешће изражава негативан емоционалан однос заснован на непожељности и одликује се повишеним и високим степеном експресивне тоналности (Ристић 1997: 173). На основу тумачења семантике глаголских експресива могуће је реконструисати схему језичке слике човека и начина њене концептуализације код носилаца српског језика, а квантитативна супериорност експресивних глагола говорења у односу на вербалне репрезенте осталих категорија радњи и стања, демонстрира лингвокултурну чињеницу да је чин говора у фокусу језичке креативности српске језичке личности и да се овај сегмент стварности (говорење и комуникација) поима као доминантна људска активност.

\footnotetext{
${ }^{4} \mathrm{C}$ посебним интересовањем руски слависти истражују глаголе говорња у народним говорима. J. А. Бесонова поставила је методичку основу компоненцијалне анализе дијалекатских глагола говорења и сврстала их у јединствено микропоље, које функционише као фрагмент „поля речи“ (Бессонова 2008). Критеријум по којем се одређује да ли глагол припада датом пољу јесте постојање субјекта (обавезна позиција) и објекта (необавезна позиција) који успостављају контакт помоћу језичких јединица (Бессонова 2011). Иста ауторка проучавала је семантику глагола говорења у орловским говорима са структурног, комуникативног и културолошког аспекта и према циљу говорног чина, односно централним семама ('произносить', 'выражать мысль', 'сообщать', 'взаимодействовать', 'побуждать', 'оцењивать') поделила их у шест лексичко-семантичких група (Бессонова 2001). Лексичко-семантичком анализом глагола говорења у Нижеградској области бавила се Љ. С. Коршунова, разврставши их у две подгрупе по физиолошко-акустичким и садржајно-смисленим особеностима говорног акта: „характеризующие глаголы говореня“ и „глаголи речевого действия“ (Коршунова 2002). Семантичко-стилистичке карактеристике ЛСГ глагола говорења описала је И. А. Крилова (Крылова 1996), а парадигматска својстава метафоричких глагола у различитим аспектима говорне ситуације разматра Н. О. Кирилова (Кириллова 2006).
} 
Дијалекатским глаголима говорења и њиховом семантичком класификацијом бавила се Р. Жугић у раду Синонимски односи у лексичко-семанитичкој грруии глаголских лексема с доминанйом зборим 'говорим' у јабланичком говору (југ̈озайадно од Лесковиа) (Жугић 2011). Из овога рада преузели смо одговарајући лексички материјал којим је репрезентовано стање у домену Verba dicendi у јужноморавским говорима. ${ }^{5}$ Наша анализа заснива се на грађи ексцерпираној из дијалекатских речника говора југоисточне Србије, тако да је истраживањем обухваћен читав ареал призренско-тимочке дијалекатске области. За потребе овог истраживања сачинили смо корпус од лексема преузетих из Речника говора јужне Србије (Златановић 2011), Тимочког дијалекайског речника (Динић 2008 + допуна Речнику у рукопису), Речника говора јабланичког краја (Жугић 2005), Збирке речи из Призрена (Чемерикић, http://prepis.org) и Жаргонске лексике југіоисиочне Србије (Марковић, Трајковић 2018). Глаголске лексеме којима се означава процес говорења дистрибуиране су у денотативне номинације и експресивне јединице, а из фонда експресива екстраховани су глаголи-метафоре на основу следећих критеријума:

1. у обзир су узети глаголи који секундарном семантичком реализацијом обележавају процес говорења;

2. глаголи који улазе у семантичко поље 'говор' метафоричким значењем које се актуелизује у одређеној комуникативној ситуацији;

3. глаголске лексеме чије је секундарно значење са категоријалном семом 'говори' забележено у дијалекатским речницима;

4. глаголи који нису лексикографски евидентирани, а који у разговорном језику остварују функцију метафоричке номинације говорног процеса, нису разматрани.

5. глаголи који искључиво у контексту преобликују значење у статус именовања говорне активности и такве разговорне семантичке варијанте нису регистроване у речницима, не улазе у зону нашег истраживања.

Одабрана лексика, прецизније лексичко-семантичке варијанте речи које за своју реализацију захтевају одређени комуникативни контекст, подвргнута је когнитивно-семантичкој и функционално-стилској анализи, са лингвокултуролошким освртом, што је условило избор метода (теорија семантичког

\footnotetext{
${ }^{5}$ Анализом упутница и инпут-анализом Р. Жугић испитује синонимске односе у лексичкосемантичкој групи глаголских лексема с доминантом зборим 'говорим' и на основу лексичкосемантичке парадигме глаголе говорења у јабланичком говору разврстава у девет синонимских редова са доминантама гррдим / изірдим, галамим / изгаламим се, луиетйам, свађам се, йийам

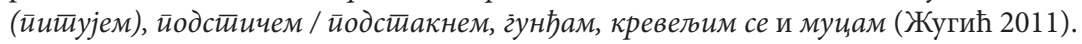

Т. Милосављевић на основу централних сема у лексичко-семантичкој групи глагола којима се означава процес говорења издваја пет подгрупа глагола говорења у српском призренском говору: 1. ЛСПГ глагола са хиперсемом 'говори', 2. ЛСПГ глагола са хиперсемом 'разговара', 3. ЛСПГ глагола са хиперсемом 'подстиче', 4. ЛСПГ глагола са хиперсемом 'досађује говором', 5. ЛСПГ глагола са хиперсемом 'изражава однос'. Даља подела врши се на основу сема нижег ранга, које конкретизују говорну ситуацију или допуњавају основне семе описујући сам говорни чин (Милосављевић 2017: 133).
} 
поља, компоненцијална анализа, метод контекстуалне анализе, метод концептуалне анализе) и детерминисало задатке рада:

1. семантичка класификација и систематизација метафоричких глагола говорења у говорима призренско-тимочке дијалекатске области;

2. структурирање микропоља глагола-метафора са хиперсемом 'говорим' у призренско-тимочким говорима;

3. откривање функционално номинативне специфике глагола са секундарним метафоричким значењем 'говори';

4. одређивање степена експресивности и функционално-стилских карактеристика дијалекатских метафоричних глагола говорења;

5. утврђивање општег и специфичног у дијалекатском микросистему глагола говорења.

6. утврђивање лингвокултурних специфичности призренско-тимочке дијалекатске личности.

Контекстуално условљене метафоричке значењске реализације глагола говорења откривају многе семантичке димензије општег концепта говор, одражавајући различите аспекте говорног чина, карактеристичне за језичко сазнање дијалекатске језичке личности. Метафорички глаголи у дијалекту имају способност да актуелизују различите аспекте говорне ситуације, ширећи семантички потенцијал дате семантичке класе. Метафоричком моделирању подвргнути су различити елементи комуникативног процеса, а с обзиром на вербалну репрезентацију за дијалекатску језичку личност најзначајнији су: смисао садржаја, комуникативна намера, мера говорења, начин говорења, интензитет гласа, почетак говорења.

\begin{tabular}{|l|l|l|l|l|l|}
\hline \multicolumn{5}{|c|}{ Елементи комуникативног процеса } \\
\hline $\begin{array}{l}\text { смисао } \\
\text { садржаја }\end{array}$ & $\begin{array}{l}\text { комуникативна } \\
\text { намера }\end{array}$ & $\begin{array}{l}\text { мера } \\
\text { говорења }\end{array}$ & $\begin{array}{l}\text { начин } \\
\text { говорења }\end{array}$ & $\begin{array}{l}\text { интензитет } \\
\text { гласа }\end{array}$ & $\begin{array}{l}\text { почетак } \\
\text { говорења }\end{array}$ \\
\hline
\end{tabular}

Метафоричко моделовање говорне ситуације располаже комплексом језичких средстава којима се дати аспекти конкретизују, варирајући општу појмовну вредност комуникативног процеса и, разлажући категоријалне компоненте, сужавају перспективизацију појединих сфера говорења.

\begin{tabular}{|l|l|}
\hline \multicolumn{2}{|l|}{ Смисао садржаја } \\
\hline $\begin{array}{l}\text { одсуство } \\
\text { смисла }\end{array}$ & досађивање \\
говором \\
\hline
\end{tabular}

\begin{tabular}{|l|l|l|l|}
\hline \multicolumn{3}{|c|}{ Комуникативна намера } \\
\hline прекоревање & $\begin{array}{l}\text { убеђивање/ } \\
\text { наређивање }\end{array}$ & $\begin{array}{l}\text { започињање } \\
\text { свађе (вербалног } \\
\text { конфликта) }\end{array}$ & оговарање \\
\hline
\end{tabular}




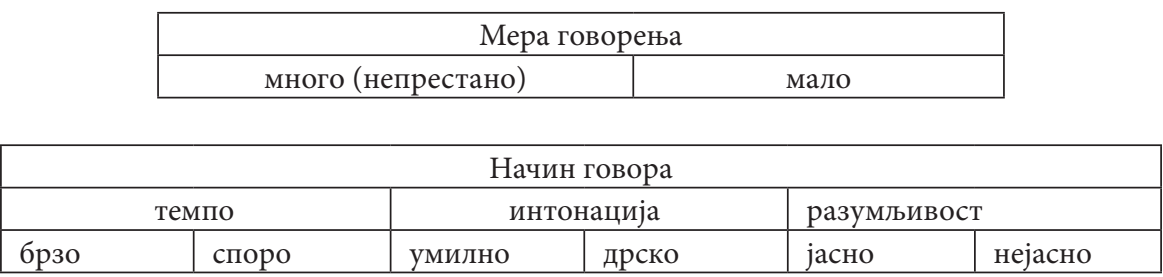

\begin{tabular}{|l|l|}
\hline \multicolumn{2}{|c|}{ Интензитет гласа } \\
\hline гласно & тихо \\
\hline
\end{tabular}

Хиперо-хипонимска идеографска структура условила је семантичку организацију микропоља и лексичко-семантичку парадигму метафоричких глагола говорења. Структура микропоља метафоричких глагола говорења обухвата шест микроскупова са надређеним семантичким вредностима који актуелизују актанте садржаја, намере, мере, начина, интензитета, почетка говорног акта.

Семантичка структура микропоља метафоричких глагола говорења

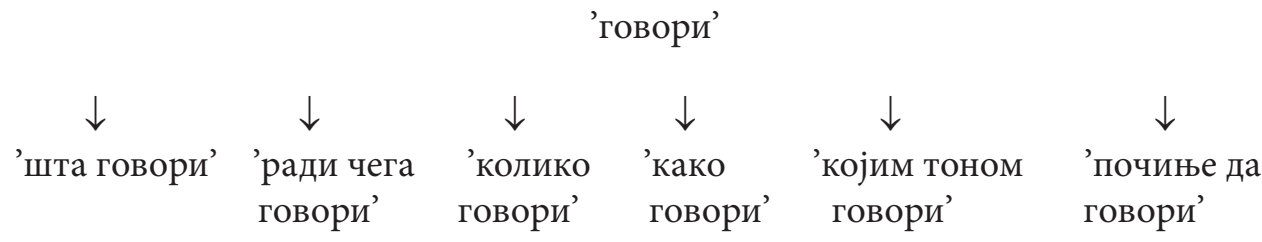

\section{1. Смисао садржаја}

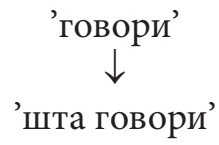

'говори којешта' 'досађује садржајем говора'

1.1. Смисао садржаја - одсуство смисла ('говори којешта'): бала́ви, баље́зга, ба́мба, бандо́ри, була́зни / була́зди, бантрљо́ше, банто́ше, ба́мба, бамбо́ри, блане́та, блебе́та, брбо́ти /брбо́ч'е, буна́ри, бьнта, бьнтрља́, га́нга, га́нта, дрнда, дрнко́ри, др'нка / др'њка, дро́би, забьнта се, жва́ка, жваго́њи, жва́њка / жва́ґћа, жвато́ри, жвањћо́ри, забантр́ља, запљеску́е се, затраку́је се, затрачку́је, зацепу́е се, изва́ли, извањћа (се), ке́ґа, лапа́ра, лапо́ри, лапрда, ломо́ти / ломо́ч'е, лу́nа, лупе́та, лу́пи, ме́ље, мла́ти, мља́ска, паламу́ди, пе́ни (се), свира, трабу́ға, тра́ка, тра́ска, тре́сне, тро́па, тртьља, тру́пи, тупи, утепује се. 
Не буна́ри, не мо́zу да те слу́шам.

Ајде, же́но, не жва́нћај.

Йде по село́ и жвањћо́ри такво́, она́кво.

Бо́ље си ћу́ти, не мьа́скај.

му́ва се по чарши́ју и сва́шта тра́ска.

Áj, не mpónaj, бо́zа ти.

Кад он тресне, да умреш од смеха.

Не тупи више!

Само се нешто утепује.

Ма свира туј нешто, не га ни слушам.

1.2. Смисао садржаја - досађивање говором ('досађује садржајем говора'): гъа́ви, да́ви, догло́че, др'нда, жва́ка, жвако́ше, заврзу́је, затраку́е се, затлики́је

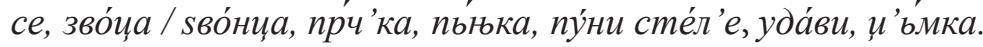

Ми́кни ми се од гла́ве, не́мој ви́ше да ме гњи́ви.

До́ста бре́, ми́кни ми се од гла́ве и не́мој ви́ше да ме да́вии с те́ј тво́је пала́вре.

До́ста де́, што́ прич'каш ту́ј све́јено?

До́ста де́, до́кл'е ч'е ми й'ьмкаш ту́j?

Ми́кни ми се од гла́ву, не́ ми завр́зуј ту́ј теке гл е́ј сво́jу рабо́ту.

Микрогрупа глагола која репрезентује аспект садржаја говорења грана се по садржају својих конституената у два ужа скупа. Један окупља лексеме којима се обележава потпуно одсуство смисла говорења, док је други значењски усмерен ка адресату, тј. његовој емоционалној реакцији на садржај говорења. Синонимске метафоре интегрисане семантичком компонентом 'говори којешта' бројчано надмашују остале скупине, што манифестује примарну позицију овог елемента у поимању комуникације. Метафоре које реферирају на испразност онога што је изречено најчешће су мотивисане звучним ефек-

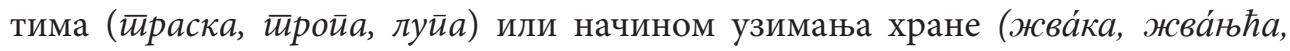
жвањћópu, жвато́ри, мља́ска). Објективно негативан семантички садржај метафоричким преносом додатно је истакнут, при чему се интензивира степен експресивности и изражава субјективни став. Негативна оцена садржаја емоционалније је изражена глаголима са интегрално-диференцијалном семом 'досађује говором', који углавном асоцирају са физичким злостављањем (да́ви,

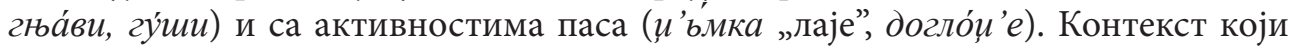
активира пренос глаголске номинације на садржај који примарно није у вези са сфером говорења ситуационо је детерминисан и може бити језички и ванјезички условљен. Садржај комуникације провоцира субјективну оцену слушаоца ('то је бесмислено, глупо'), покреће његов емотивни однос ('то је досадно') и из пасивне га ставља у позицију активног учесника - говорника, док екстралингвистички фактори (сценарио по којем се комуникација одвија, који укључује параметре као што су социјални статус, социјалне улоге, узраст, околности и сл.) утичу на избор експресивне ознаке (метафоре) за чин говорења бесмислица, с наглашеним прагматичким моментом, односно с намером да то буде јасно 
особи са којом се комуницира, при чему се активира функционалностилска компонента - адресант себи даје за право да своје недопадање, гнушање, презир изрази на подругљив, груб начин. Избор експресивне, метафоричке номинације за изражавање негодовања на садржај исказа директно маркира однос између учесника комуникације и одражава изванјезички контекст који омогућава експресивни језички израз. Лексикографске илустрације уз дате лексеме сугеришу одређени тип говорне ситуације у којима се метафоричност актуелизира како би се постигао виши степен експресије, што се обично остварује у условима неформалне, фамилијарне комуникације, између саговорника међу којима постоји извесна блискост (породична или пријатељска) која обезбеђује комфорност и слободу у изражавању. Секвенце из народних говора упућују и на социјални моменат, који је важан чинилац у конструисању међуљудских односа и њихове комуникације. Запажа се извесна супериорност друштвене улоге адресанта, а стереотипни однос који допушта употребу негативно конотираног експресива је однос супружника, при чему муж с омаловажавањем третира садржај говорења жене. Адресант директно, у дијалошкој форми испољава свој став и афективно жели да забраном (која је формализована негацијом) блокира изношење садржаја, који оцењује као непримерен и испразан, или одбијањем и удаљавањем саговорника жели да прекине конверзацију у случају да му је понуђени садржај незанимљив, досадан, оптерећујући.

\section{2. Комуникативна намера}
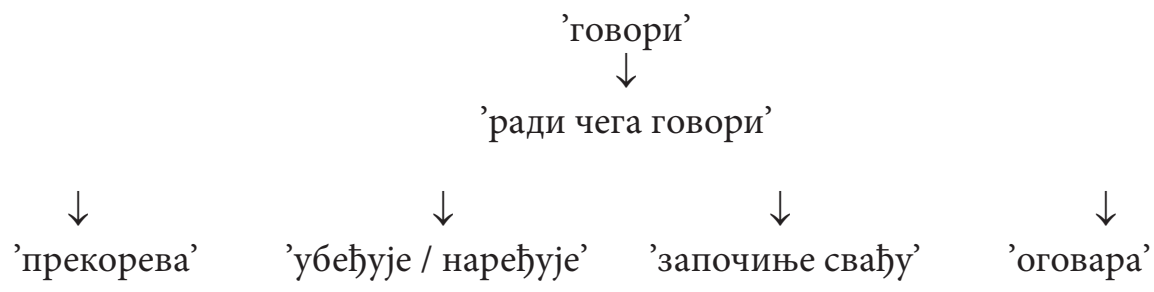

2. 1. Комуникативна намера - 'прекорева': áка, гло́ие, др'нка, дрнко́ри, ђе́бри, ђу́стри, жва́ғћа, жвањћо́ри, зво́иа / sво́нцฺа, изђи́бри, изђу́стри, иза́ка, изро́та, изру́жи, иска́нта, иска́стрим, испе́рда, иска́лпи, исме́ши, искрич, ка́нта, ка́ра (се), ка́стри, коледу́је, ља́zа, наánа, наро́ти се, наа́ка се, оља́zа, пе́рда, прока́стри, подсме́ши, ру́жи, ро́та, сколе́дује, сме́ши, сна́једе, та́лпи, ияврчи́...

Це́л ве́к си ме глода́л, па си реши́л да ме догло́иеш.

Не́чу да и́м у кава́ну да ми по́сле она́ј моја́ ба́ба не жва́нћа.

Пу́шти ју нек си жвањћо́ри.

Ка́ра ме башта́ кьд се заба́им из шко́лу.

A ви́ два́ ме наапа́сте ни кри́вога, ни ду́жнога. - На́апа га, котлйче га ýчини. - Што́ ти вала́mе да гу наánаш та́ко пред све́m.

Не мо́г д и́м с ва́с у кава́ну, ел кьд се врнем до́м, она́ј мо́ја и́ма да ми цฺврчи́. 
2. 2. Комуникативна намера - 'убеђује / наређује': ба́ри, декњу́е, ка́ни, накове́нта, нату́тка, подбади́ња, подбоде́, подбо́дне, подму́не, ре́ди, ту́тка, упе́за, упези, ушрафи...

Декьу́ем му, ко да не, али о́н то́ј не зарезу́је.

На́ковента га бра́та ми да ку́пи пла́u.

Онај дечко ичело вече бари ону иуру.

Једва ме упезао да му помогнем.

Упезио сам ћалета за паре.

Уирафио га да му фарба ограду.

2.3. Комуникативна намера -’започиње свађу': бодрика, гала́ти, гло́дне, глои'е се, дока́чи се, заánе, зда́ви се, заи́да се, издри́бла, изри́ба, ка́ра се, кајдису́е, кајди́ше, ко́мса се, ко́шка се, наа́па, наке́ља се, поко́шка се, покарамба́са се, поцаве́ља се, поцамба́си, поца́па, пре́чка се, спре́чка се, те́рка се, ца́па се, цаве́љь, цољьи́ви се, цоо́са се...

Кьд се напи́е, кајди́ше на љу́ђе.

Што се, бре́, то́лко ироља́виш, сми́ри се.

2.4. Комуникативна намера - 'оговара': беди́, вре́ви с поло́вин у́ста, жва́ка, жвако́ри, жва́њћа, жвањћо́ри, жвато́ри, иску́ди, испљу́је, ла́је, олајава, опа́ьька, пљу́је...

Кво́ си ти жвака́ла од ме́н по сало́, курвољи́но една́?

Немо́ј да те чу́јем па́ да жва́њћаш нешто́ од ме́н.

Нешйо си лајао о мени. - Немој да лајеш ирроииив юега, не заслужује.

У оквиру глаголске групе која секундарно номинује процес говорења налази се солидан број лексема које актуелизују интенцију субјекта, манифестујући однос адресанта према адресату. Комуникативна намера говорника концептуализује се као прекоревање, убеђивање, наговарање, започињање свађе, вербални конфликт и оговарање. Управо је сегмент комуникативне стварности који одражава вербални контакт, односно изражава однос према саговорнику најактивнији и најпродуктивнији у језичком сазнању говорника са југоистока Србије, што би се могло означити као лингвокултурна специфичност призренско-тимочке језичке личности и као одлика менталитета ове говорне заједнице. Међуљудски односи и намера којом се подстиче конверзација у центру су комуникативне ситуације за носиоце призренско-тимочких говора, с обзиром да је ова група глаголских метафора бројчано супериорна у домену глагола говорења, парадигматски комплексна, семантички раслојена, функционално искоришћена, стилски разноврсна. У говорним ситуацијима прекоревања и провоцирања расправе наглашена је емоционалност говорника која, као изванјезички контекстуални елемент, учествује у креирању семантичке структуре експресива којима дијалекатска језичка личност маркира акт говорења који интиутивно спознаје као вербалну агресију. Стање субјекта говорења и ин- 
тензитет емоције којом изражава своју комуникативну намеру рефлектују се у конотативни садржај глаголске ознаке и модификују полазно значење механизмима метафоризације, мотивисаном најчешће понашањем животиња. Јединице овога типа експлицитно одражавају аспект емоционалног односа говорника према саговорнику. Прекоревање и иницирање вербалног конфликта адресант доживљава као досађивање, оцењује га као негативан поступак и свој став према репресивном говорном чину изражава платисемичним метафорама које семантичку дифузност остварују у различитим лексичко-семантичким микрогрупама, а у оквиру исте категорије објективне стварности. Такве су, на пример, лексеме жваюћа, жватиори, жваюћори чија функционална продуктивност проистиче из капацитета да изразе више аспеката комуникативне ситуације („1. говори којешта; 2. оговара; 3. прекорева”), што упућује на концептуалну блискост и когнитивну повезаност ових димензија комуникативног дискурса.

\section{3. Мера говорења}
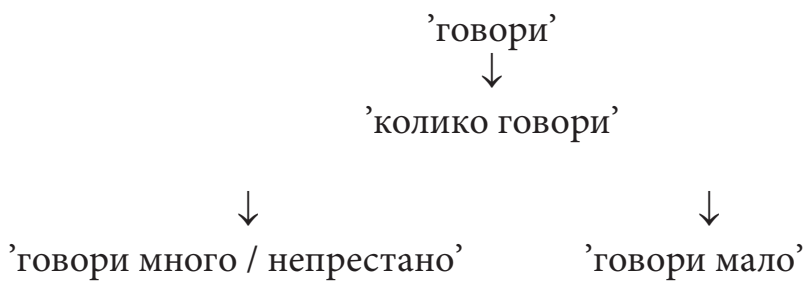

3. 1. Мера говорења ('колико говори') - 'говори много / непрестано': бала́ви, ба́мба, блебе́ће, блебе́та, га́нга, га́нта, др́⿱ља, др'нда, дро́би, кла́па, ломо́ти, ме́ље, тра́ка...

Само балави, не могу више да га слушам.

Ништа не радиш, само нешто блебећеш.

Кад по́чне да ба́мба, у́ши да ме забо́лив, са́мо мла́ти не́што.

Ма́, не́ ли га зна́м, га́нга куде сти́гне.

Немо́j мно́го да дро́биш ел не́че да бу́де до́бро за те́б.

Тра́ка како траката́љка у водени́иу.

3. 2. Мера говорења ('колико говори') - 'говори мало': економише...

Он економище и кад ирича.

Диференцијација конституената одражава поларитет који почива на дихотомији квантификатора 'много' / 'мало' уз категоријални знак 'говори'. Уочава се непропорционалност у попуњености ових сегмената на дијалекатској језичкој слици света, што демонстрира чињеницу да је за носиоце југоисточних српских говора непрестано и неумерено причање иритантно, тим пре што корелира са изношењем бесмисленог садржаја, те да за означавање овог 
процеса говорници бирају пејоративне метафоре високог степена експресивности. Концептуална повезаност параметара који реферирају на квантитет и квалитет изговореног садржаја рефлектује се у значењској интерпретацији појединих језичких ознака (нпр. бамбам „брбљам, вревише говорим, говорим којешта“; гангам „много причам; говорим којешта”; йракам „много причам; причам којешта") и детерминише парадигматске везе унутар скупа. Умерена говорљивост и ћутљивост нису нарочито инспиративни дијалекатској језичкој личности и не подлежу њеној језичкој креативности, с обзиром да се у традиционалном систему вредности одмереност у говору поима као идеални комуникативни сценарио и пожељна, прототипична црта менталитета.

\section{4. Интензитет гласа}

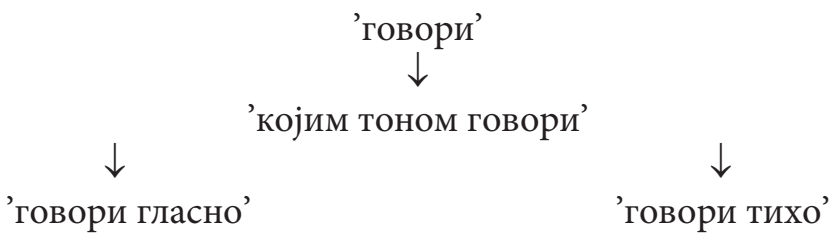

4.1. Интензитет гласа ('којим тоном говори') - 'говори гласно': вречи́, вре́кне, вркти́, гра́ка, грми́, дре́ка, заржи́, изгаси́ра се, изди́за се, истри́ша се, кре́ка, натри́ше се, пра́ска, разгрми́ се, разрове́ се, разиабо́ли се, разцака́ли се, раскре́ка се, режи́, рове́, чапа́ти се, цабо́ли...

Пушти га нека пра́ска, ч’е се испра́ска, па че му про́и’е л'ути́на.

Ко́zа ми́сл'иш да пла́шиш те грмми тол'и́ко, ме́не л'и?

Што́ се, бре́, то́лко издизаш, као да ти гла́ву ки́дамо?

Што́ ти је, мо́ре ч’ове́ку, те си се та́ко разгрме́ја?

Извини што сам се синоћ изгасирао на тебе, био сам љут.

4.2. Интензитет гласа ('којим тоном говори') - 'говори тихо': дудо́ри, вре́ви с поло́вин у́ста.

Чујјем не́ћи дудо́ре, ал и не ви́дим.

Спољашњи елементи говора најподложнији су метафоричком моделирању, а један од аспеката говора који подлеже семантичкој деривацији јесте интензитет звука. Глаголске метафоре из акустичког домена говорења регуларно указују и на емоционално стање говорника, које се конкретизује диференцијалном квалитативном семом 'гласно' и језички се интерпретира семом интензитета, односно појачаном тоналношћу. Микрогрупа са надређеним семантичким знаком 'којим тоном говори' шире реферира на начин говорења, варирајући интегралну семантичку компоненту актуелизацијом сема конкретизатора 'говори гласно, ' говори тихо' које поларизују скуп и детерминишу парадигму уну- 
тар њега. Парадигматски односи међу члановима имају антонимски карактер, с тим што је, на основу лексичког састава и примера, очигледно да је перцепција усмерена на гласан говор, што имплицира једну карактеристику поимања стварности - повишен глас иритира дијалекатску језичку личност више него тихо говорење. Несразмеран однос антонимски устројених лексичких блокова манифестује лингвокултурну чињеницу да гласно говорење одступа од прототипичне комуникативне ситуације и да се говорни чин поима као пристојан, сведен разговор, без вике и повишеног тона. Неприхватљивост оваквог облика вербалног изражавања језички се манифестује избором метафора когнитивно заснованим на вези између звукова из природе и људског гласа. Емоционално стање учесника комуникације вербализује се афективним тоном и појачаним интензитетом звука (повишеним гласом) који говорника најчешће асоцира на оглашавање животиња (врана, гавран - гра́ка, коза - вре́ка, вречи́, вректи́, вре́кне, јарац - дре́ка, пас - режи́, заржи́, жаба - кре́кам, раскре́кам се), на збивања у природи (грмљавина - грми́, разгрми́ се), на ломљаву, пуцање (пра́ска, испра́ска се). У синонимском реду метафора са интегрално-диференцијалним знаком 'говори гласно' сема интензитета интонације варира на вишим степенима скале, што уноси одређену дозу градације међу синонимима. У жаргону југоисточне Србије је забележена метафора изгасира се којом се сигнификује стање субјекта у ситуацији када виком, која је обично усмерена на саговорника, покушава да избаци нагомилани бес. Ослобађање емотивног притиска вербалном афектацијом појмовно се доводи у везу са испуштањем гаса. Одабир деривационих база за семантичку трансформацију садржаја преко квазистереотипа носе и чувају информацију о наивној језичкој слици света призренскотимочке заједнице.

Сложеност овог микросистема огледа се у преклапању појединих говорних аспеката, најчешће јединица којима се интерпретирају неки од унутрашњих и спољашњих елемената. У истој концептуалној равни су намера говорника и интензитет гласа ('прекорева' / 'гласно'; 'оговара' / 'тихо'), комуникативни садржај и мера говорења ('говори којешта' / 'пуно, много говори'). Квантитативна доминација глаголских лексема које реферирају на садржај исказа и на тон гласа демонстрирају опште црте у поимању и доживљају процеса говорења у свести призренско-тимочке дијалекатске личности.

\section{6. Начин говора}
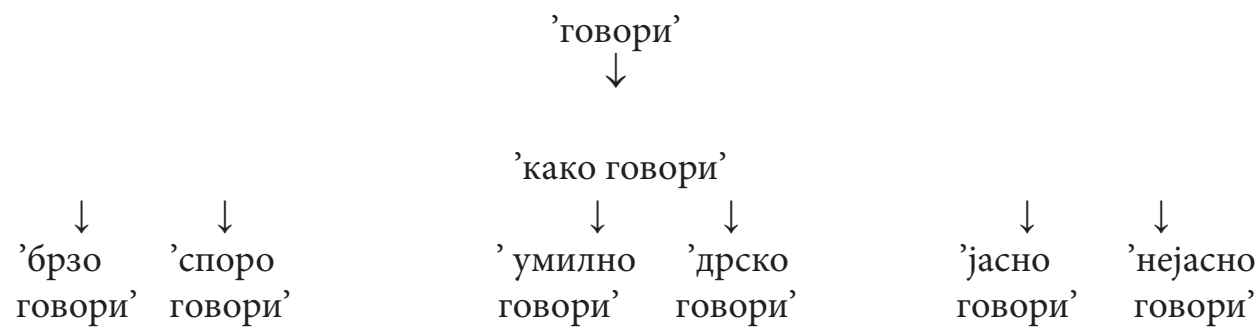


\section{1. Начин говора ('како говори') - темпо}

6. 1. 1. Начин говора ('како говори') - темпо ('брзо говори'): блебе́та, дрннда, ве́ргла, ломо́ти...

Кад научи, само верг̃ла.

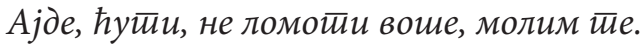

6.1.2. Начин говора ('како говори') - темпо ('споро говори / одуговлачи'): гуюжви, жље́би се, мрчи́, цеди...

Ако тре́бе не́где д и́деш, ти́ немо́ј мло́го да гу́жвиш, веч се спрему́ј и оти́du.

Му́ка ми припа́дне кьд ва́не да се жље́би.

Ајде не мричи!

6.2. Начин говора ('како говори') - интонација

6.2.1. Начин говора ('како говори') - интонација ('умилно говори'): гугу́че / гугу́ч'е, гугуту́е, гу́ка / гуч'и, гу́кне, ма́зи се, цврку́ће....

Гугуч 'ámе, гугуч 'ámе, па за́спа, зла́то матери́но.

Ка́ко гу́ч'и о́на, мо́ри, ч'е ре́кнеш гу́ка ни́ка голуби́ца. - Све́јено што гу́ка, ка да о́ч 'е ни́што да ти ре́кне. - До́икан гу поч 'е́ло да гу́ч'и то́j дево́јч'е.

На ма́, на ма́, те́ке гу́кне по ко́ј пу́m. - Гу́кни га, гу́кни га де́. - Та́ко је о́но прокл'е́то, не́ч'е да гу́кне.

6.2.2. Начин говора ('како говори') - интонација ('дрско говори'): бре́иа се, бре́ине се, ду́са се, ду́сне се...

Што́ се бре́цฺаш, ку́ји ти је ђа́вол?

Túће се бре́цне на чове́ка.

А му нешто́ ре́кнеш, о́дма се ду́са.

6.3. Начин говора ('како говори') - разговетност

6.2.1. Начин говора ('како говори') - разговетност ('јасно говори'): пое́ / пе́ва, ве́ргла...

6.2.2. Начин говора ('како говори') - разговетност ('нејасно говори'):

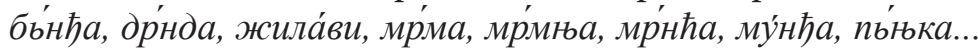

Ај не дрндај та́м.

Еј, немо́ј то́лко да га жила́виш, казу́j га дире́кно.

Са́мо га ви́диш ко мрда с бра́ду и некво́ мр́ма.

Немо́ј да ми мр́нћаш, веч вре́ви ко се вре́ви.

Микроскупови у домену начина говорења имају антонимску структурну организацију, пресликавајући на наивној језичкој слици света крајње скаларне вредности. Интонативни аспект појмовно обједињује умилно, нежно говорење (гугу́че, гу́ка) и дрско обраћање. Темпо говора провоцира семантичку трансформацију примарног садржаја, јер су обе димензије ритма говорења когнитивно интригантне - 'брзо говори' (ломо́ти, блебе́та, ве́ргла), 'одуговлачи' 
(гу́жви, жље́би се, мрчи́). Неразговетан говор такође је маркиран експресивним знаком (др́нда, жила́ви), као један од чинилаца ометања вербалног контакта. Аудио-ефекат који производи спољна форма процеса говорења на комуникативном плану, на плану декодирања прима се као стилски ефекат који се на језичком нивоу двоструко постиже: адхерентном експресивношћу - семантичком деривацијом и инхерентном експресивношћу, формалним показатељима необичности (Ристић 2004: 49). Експресивна модалност по семантичком садржају реализује се различитим моделима метафоризације, међу којима су доминантни зооморфна метафора (гугу́че / гуги́ч'е, гугуту́е, гу́ка / гучи́, гу́кне, цврки́ће) и метафора физичког дејства (це́ди, дрнда, ломо́ти, гу́жви, жље́би се, dýca ce). Аспекти који отежавају комуникацију мотивишу језичку продуктивност и инспиришу призренско-тимочку језичку личност, која незадовољство неразговетним и нејасним начином говорења демонстрира не само неочекиваним семантичким трансформацијама, којима се појачава непосредни утисак, већ и афективним гласовним склопом са примесама ономатопеје. Нарочитим типовима афиксалне деривације, пејоративима и хипокористицима, носиоци југоисточних српских говора изражавају презрив, али и подсмешљив однос према акустичко-физиолошким и когнитивним факторима који нарушавају конвенционалан образац комуникације. Том контексту припадају афирмативно конотиране метафоре са дијагностичким семантичким обележјем 'јасно говори', док прототипичне (међу)вредности у другим поткатегоријама којима се идентификује спољна форма говора нису лексикализоване. Вербализовани су они елементи комуникативне стварности који ремете услове пристојне и пријатне конверзације и управо ти језички знаци на дијалекатској језичкој слици света репрезентују лингвокултурни спецификум призренско-тимочке заједнице и особености њеног менталитета које се очитују у говору и говорењу (екстровертност, непосредност, повишена афективност, емоционалност).

Контекстуално условљене метафоричке реализације са значењем глагола говорења откривају многе семантичке димензије општег концепта говор, одражавајући различите аспекте говорног чина, карактеристичне за језичко сазнање дијалекатске језичке личности. Метафорички глаголи имају способност да актуелизују различите аспекте говорне ситуације, ширећи семантички потенцијал дате семантичке класе. Когнитивна вредност метафоричких глаголских реализација повезана је првенствено с њиховом могућношћу да синкретично моделују говорну ситуацију. Слојевитост и фигуративност семантичког садржаја дају способност глаголу-метафори да истовремено означи различите елементе комуникативног процеса.

Општа тенденција, примећена и у призренско-тимочким говорима, јесте флексибилност спољашњих компонената акта говорења и подложност семаконкретизатора 'интензитет звука"брзина (темпо) говора' и 'нејасност говора' семантичкој трансформацији (грми́, пра́ска, пршти́, кре́ка, ла́је, ри́ка, рове́, и́рла, чапа́ти, разиабо́ли се, разиако́ли се; ломо́ти, ме́ље, брбо́ће; му́мла, мр́мња, ца́мка). Карактеристике садржаја исказа лако се варирају, тако да се чиниоци интегри- 
сани семантичким знаком 'говори којешта' који реферирају на садржај говора укључују у регуларне механизме семантичке деривације, што је универзална појава, карактеристична и за испитивану говорну заједницу (ба́je, дрнда, жва́ка, ме́ље, тро́nа, тра́ска, тр́mља). Лингвокултурна специфичност ове говорне зоне огледа се у интензивном моделовању елемената комуникативне интенције, посебно подстрекивања вербалног сукоба (гло́це, ка́стри, изврчи́, гло́и'е се, дока́чи ce, заáne, зда́ви се, заи́да се, изри́ба, ко́шка се, наána, пре́чка се, ца́na ce).

Глаголи-метафоре којима се на дијалекатској језичкој слици света вербализује концепт говорења поседују велики креативни потенцијал који се актуелизује у говорном чину под утицајем језичког и изванјезичког контекста. Поред општих законитости које важе у домену семантичке деривације у сфери говорења, као неисцрпном извору лексичке продукције, дијалекатске метафоричке номинације имају сопствене особености које су контекстуално условљене, пре свега екстралингвистичким фактором - комуникација се одвија у неформалним околностима, у породичном, комшијском, окружењу, у опуштеном, природном, локалном амбијенту, са саговорницима уједначеног социјалног статуса (дијалекат), приближног узраста (жаргон), тако да лексеме из овог круга припадају разговорном функционалном стилу са израженом тенденцијом да експресивно маркирају говорну ситуацију. Експресивни језички израз и субјективна интерпретација говорног акта умогоме су последица особина дијалекатске језичке личности: непосредност, отвореност, слобода изражавања, емоционалност, афективност. Ово је један од приступа дијалекатском микросистему глагола говорења и један од могућих модела за тумачење семантике глаголских експресива са циљем реконструисања схеме језичке слике човека и начина њене концептуализације код носилаца југоисточних српских говора.

\section{Литература}

Бессонова, Ю. А. (2001). Семанйика диалекйных гллаголов речи в орловских говорах и отиражение в ней мировосириятиия их носииелей [Online]. Автореф. дис.. Доступно на: http://www.dissercat.com/content/semantika-dialektnykh-glagolov-rechiv-orlovskikh-govorakh-i-otrazhenie-v-nei-mirovospriyati\#ixzz33knebfY7 $\left[\begin{array}{ll}27 . & 3 .\end{array}\right.$ 2019]

Бессонова, Ю. А. (2011). Семантическое микрополе глаголов речи в литературном языке и говорах. В: Воирросы йеории и йракитики, № 1 (8), 33-37.

Васильев, Л. М. (1971). Семаниичческие классы гллаголов чувсиива, мысли, речи. Очерки ио семанииике русского гілагола. Уфа.

Динић, J. (2008). Тимочки дијалекайски речник. Београд: Институт за српски језик CAHY.

Жугић, Р. (2005). Речник говора јабланичког краја. Срйски дијалекйолошки зборник, LII, 1-461.

Жугић, Р. (2011). Синонимски односи у лексичко-семантичкој групи глаголских лексема с доминантом зборим 'говорим' у јабланичком говору (југозападно од Лесковца). Зборник радова Филозофског̄ факулиетеиа, XLI , 51-72. 
Златковић, М. (2011). Речник говора југ̃а Србије. Врање: Аурора.

Кириллова, Н. О. (2006). Мейаборические номинации в семаниичческом йоле г̈лаголов речи, [Online]. Доступно на: https://cyberleninka.ru/article/v/metaforicheskienominatsii-v-semanticheskom-pole-glagolov-rechi [27. 3. 2019]

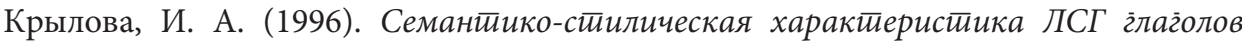
pечu. [Online]. Доступно на: http://cheloveknauka.com/semantiko-stilisticheskayaharakteristika-lsg-glagolov-rechi [29. 3. 2019].

Марковић, Ј. и Трајковић, Т. (2018). Речник жаргонизама јужне иругее. Ниш: Филозофски факултет.

Милосављевић, Т. (2017). Лексика српског призренског говора. Срйски дијалекииолошки зборник, LXIV, 1-602.

Ристић, С. (1977). Лексичка семантика експресивних глагола у савременом српском језику. Зборник Матиице срйске за филолог̈ију и лингівистиику, 40, 1, 167-176.

Ристић, С. (2004). Ексирресивна лексика у срйском језику. Монографије 1. Београд: Институт за српски језик САНУ.

Ристић, С. (2006). Глаголи говорења у функцији метајезичких модификатора. Наш језик, 37, 1/4, 15-24.

Ристић, С. (2007). Глаголи говорења у функцији локутивних карактеризатора говорног поступка.

Зборник Майице срӣске за филолог̈ију и тингівистиику, 50, 793-805.

Сазыкина, М. И. (2006). Метафорические номинации в семантическом поле глаголов речи [Online]. Доступно на: http://www.rusnauka.com/22_PNR_2012/ Philologia/3_115079.doc.htm [27.3. 2019].

Стернин, И. А. и Саломатина, М. С. (2011). Семантический анализ слова в контексте. Воронеж: Истоки.

Цыганова, Е. Б, (2008). Метафорическая номинация речевой деятельности: на материале, глаголов русского и английского языков [Online]. Доступно на: https:// www.dissercat.com/content/metaforicheskaya-nominatsiya-rechevoi-deyatelnostina-materiale-glagolov-russkogo-i-angliisk [27. 3. 2019].

\section{Tanja Milosavljević}

\section{CONTEXTUALIZED METAPHORICAL REALIZATIONS OF VERBS IN PRIZREN-TIMOK SPEECH}

The basic functions of speech, physiological-acoustic, communicative, emotional and cognitive, have shaped the lexical-semantic system of verbs of speech, which represents the dominant linguistic form in all processes of communication. The model and content of communication are determined by the semantic potential of verbal lexemes, which are realized in a specific speech situation. The contextually conditioned metaphorical semantic realizations of verbs of speech reveal numerous semantic dimensions of the general concept of speech, reflecting the various aspects of the act of speaking, characteristic of a linguistic knowledge of a dialectical linguistic personality. Metaphorically, verbs have the ability to realize various aspects of a speech situation, broadening the semantic potential of the given semantic class. The cognitive value of 
metaphorical verbal realizations is connected primarily to their ability to syncretically model the same speech situation. Various elements of the process of communication have been subjected to metaphorical modelling, and the analysis has determined that what is most susceptible to semantic transformation are the external components of the act of speaking differentiated by semes-specifiers: 'the intensity of the sound' (grmi, praska, pršti, kreka, laje, rika, rove, urla, čapati, razdžaboli se, razdžakoli se), 'the speed (tempo) of speech' (lomoti, melje, brboće), 'the clarity of speech' (mumla, mrmnja, $d z a m k a)$ and the factors integrated by the semantic indicator 'talking gibberish' which refers to the content of the speech (baje, drnda, žvaka, melje, tropa, traska, trtlja). The verbs-metaphors that are used to verbalize the concept of speech at the linguistic image of the world possess a great creative potential which is realized in the speech act under the influence of linguistic and extralinguistic contexts.

tanja77nis@gmail.com 